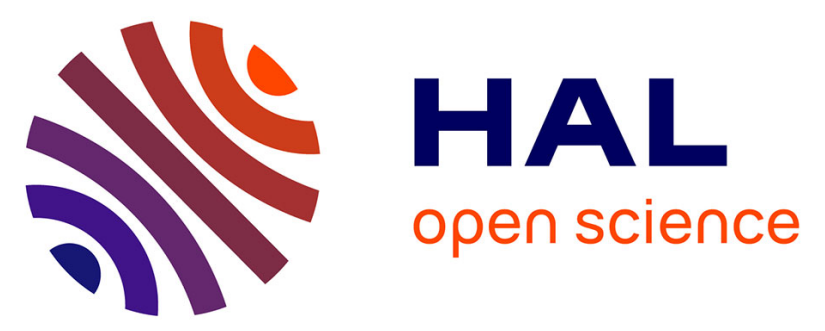

\title{
Evaluating next-generation sequencing in neuromuscular diseases with neonatal respiratory distress
}

\author{
Marie-Céline François-Heude, Ulrike Walther-Louvier, Caroline Espil-Taris, \\ Pierre Beze-Beyrie, Francois Rivier, Eloise Baudou, Emmanuelle Uro-Coste, \\ Valérie Rigau, Marie Laure Martin Negrier, John Rendu, et al.
}

\section{To cite this version:}

Marie-Céline François-Heude, Ulrike Walther-Louvier, Caroline Espil-Taris, Pierre Beze-Beyrie, Francois Rivier, et al.. Evaluating next-generation sequencing in neuromuscular diseases with neonatal respiratory distress. European Journal of Paediatric Neurology, 2021, 10.1016/j.ejpn.2021.01.011 . hal-03147695

\section{HAL Id: hal-03147695 \\ https://hal.science/hal-03147695}

Submitted on 22 Mar 2021

HAL is a multi-disciplinary open access archive for the deposit and dissemination of scientific research documents, whether they are published or not. The documents may come from teaching and research institutions in France or abroad, or from public or private research centers.
L'archive ouverte pluridisciplinaire HAL, est destinée au dépôt et à la diffusion de documents scientifiques de niveau recherche, publiés ou non, émanant des établissements d'enseignement et de recherche français ou étrangers, des laboratoires publics ou privés. 


\title{
Evaluating next-generation sequencing in neuromuscular diseases with neonatal respiratory distress
}

\author{
Marie-Céline François-Heude ${ }^{\mathrm{a}, 2}$, Ulrike Walther-Louvier ${ }^{\mathrm{b}, 4}$, Caroline Espil-Taris ${ }^{\mathrm{c}, ~} 4$, \\ Pierre Beze-Beyrie $^{\mathrm{d}, 4}$, François Rivier ${ }^{\mathrm{b}}{ }^{4}$, Eloise Baudou ${ }^{\mathrm{a}, 4}$, Emmanuelle Uro-Coste ${ }^{\text {e, f, } 4}$,

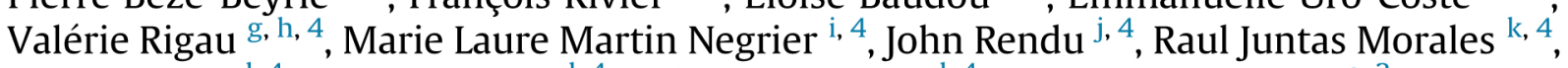 \\ Henri Pégeot ${ }^{1,4}$, Corinne Thèze ${ }^{1,4}$, Delphine Lacourt ${ }^{1,4}$, Anne Cécile Coville ${ }^{\mathrm{a}, 3}$, \\ Mireille Cossée ${ }^{k, 1,1,2}$, Claude Cances ${ }^{a, *, 1,2}$

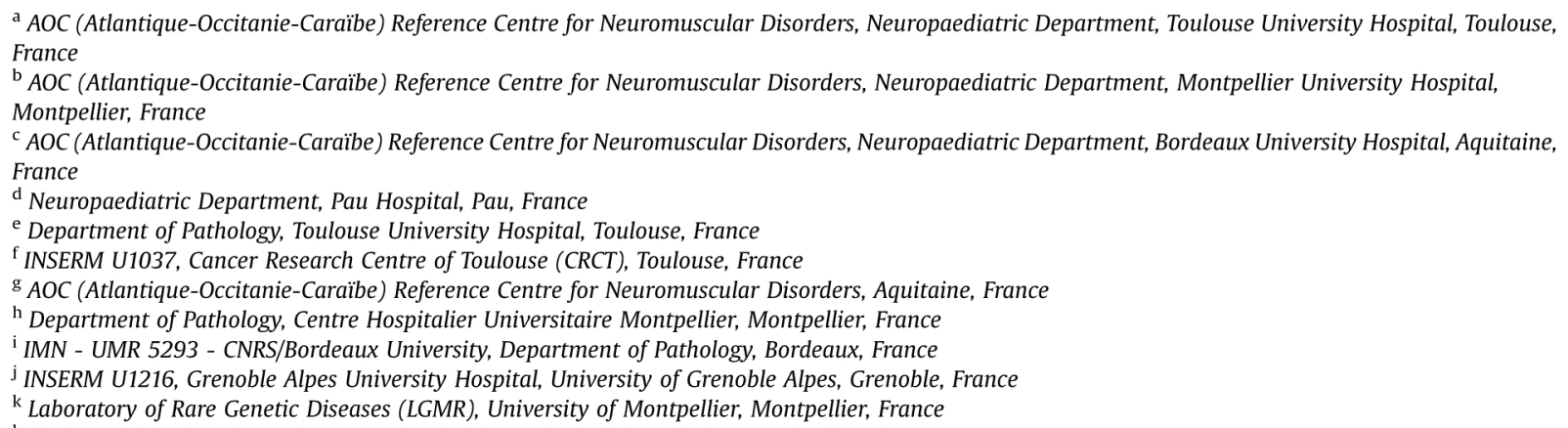

\section{Keywords:}

Congenital myopathy

Congenital muscular dystrophy

Neuromuscular diseases

Neonatal respiratory distress

Next-generation sequencing

\begin{abstract}
A B S T R A C T
With the exception of infantile spinal muscular atrophy (SMA) and congenital myotonic dystrophy 1 (DM1), congenital myopathies and muscular dystrophies with neonatal respiratory distress pose diagnostic challenges. Next-generation sequencing (NGS) provides hope for the diagnosis of these rare diseases.

We evaluated the efficiency of next-generation sequencing (NGS) in ventilated newborns with peripheral hypotonia. We compared the results of our previous study in a cohort of 19 patients analysed by Sanger sequencing from 2007 to 2012, with a diagnostic yield of $26 \%$ (5/19), and those of a new retrospective study in 28 patients from 2007 to 2018 diagnosed using MyoPanel, a neuromuscular disease panel, with a diagnostic yield of $43 \%$ (12/28 patients). Pathogenic variants were found in five genes: ACTA1 $(\mathrm{n}=4$ patients), RYR1 $(\mathrm{n}=2), \operatorname{CACNA1S}(\mathrm{n}=1), N E B(\mathrm{n}=3)$, and MTM1 $(\mathrm{n}=2)$.

Myopanel increased the diagnosis of congenital neuromuscular diseases, but more than half the patients remained undiagnosed. Whole exome sequencing did not seem to fully respond to this diagnostic limitation. Therefore, explorations with whole genome sequencing will be the next step.
\end{abstract}

\footnotetext{
* Corresponding author.

E-mail address: cances.c@chu-toulouse.fr (C. Cances).

1 These authors contributed equally to this work.

2 These authors contributed to medical evidence, data collection, article writing and reading.

${ }_{3}^{3}$ These authors contributed to article writing and reading.

${ }^{4}$ These authors contributed to data collection and scientific expertise.
}

\section{Introduction}

In the neonatal period, respiratory distress associated with peripheral hypotonia may be an early sign of neuromuscular disease [1]. With the exception of infantile spinal muscular atrophy (SMA) and congenital myotonic dystrophy 1 (DM1), congenital myopathies and congenital muscular dystrophies constitute the majority 
of these diseases, with the involvement of more than 100 known mutated genes [1-7], some of which are common to both groups, such as the RYR1 and SEPN1 genes [5,8,9]. This clinical presentation may also be indicative of early onset neuromuscular junction pathologies or congenital myasthenic syndromes [10-12]. Differential diagnoses predominantly rely on the exclusion of metabolic myopathies, congenital myotonic dystrophies, congenital neuropathies, SMA and Prader-Willi syndrome (PWS) [13,14].

Currently, the correlation between the severity of the neonatal impairment and the subsequent functional prognoses or predictors of survival [15], cardiorespiratory injury, or risk of developing malignant hyperthermia during anaesthesia, is not already obvious. An accurate early diagnostic tool is thus needed [16,17] to establish the prognosis, implement preventive therapeutic strategies [18], and initiate the commensurate genetic counselling and support.

The clinical phenotype of neonatal neuromuscular diseases is variable and nonspecific [16]. Until the advent of high-throughput gene sequencing techniques, the diagnostic approach consisted of collecting a set of clinical, biochemical, electrophysiological, anatomopathological, cerebral, medullary and muscular iconographic data and performing molecular analyses of individual candidate genes by Sanger sequencing $[1,19,20]$. However, this approach was often arduous, incomplete, time and cost consuming, except in cases of SMA and DM1.

In recent years, the development of high-throughput sequencing techniques has improved diagnostic efficiency and cost-effectiveness. Next-generation sequencing (NGS) can examine several genes or genomic regions simultaneously. This process is faster, less expensive, and more sensitive and specific than conventional gene-by-gene Sanger sequencing. It encompasses several different approaches depending on the size of the genome to be sequenced, with gene panel sequencing (GPS) for specific genes known to be implicated in a given type of pathology or symptoms, whole exome sequencing (WES) for all coding regions (exons), and whole genome sequencing (WGS) for the entire genome, which includes all coding and non-coding regions. RNA sequencing (RNAseq) is the study of the transcriptome to detect promoter or splicing errors [21,22]. Until recently, WGS and RNAseq were deemed too expensive and were therefore rarely used in routine clinical practice, so there is precious little available data concerning molecular diagnosis using these techniques [16]. According to the literature, GPS [23-40] and WES [36,41,42] offer a diagnostic yield of between 15 and 83\% and between 29 and 67\% respectively, for neuromuscular diseases. For WES this increases to $73 \%$ in consanguineous cases [43]. GPS, with a sequencing coverage of $94-99 \% \mathrm{vs.}$ 80-85\% for WES, presents several advantages: greater diagnostic efficiency, faster results and lower cost [30]. In their studies, Biancalana and Laporte reported that the cost for GPS of about 150 genes is usually equivalent to the cost for analysing 3-4 genes of medium size using Sanger sequencing[44]. Schofield et al., after an economic analysis on 56 patients suspected of having nemaline myopathy or congenital muscular dystrophy, concluded that their neuromuscular disease panel (464 genes) cost less than a quarter of the cost of the traditional diagnostic investigations pathway [30]. In addition, a trio analysis of the patient and both parents increases GPS efficiency by 10-20\% compared to an isolated analysis of the patient alone. Analysing both parents helps to differentiate de novo from inherited pathogenic variants and also eliminates nonpathogenic genetic polymorphisms [9,42].

We previously carried out a retrospective study of diagnostic strategy by Sanger sequencing in 19 children with neuromuscular disease with neonatal respiratory involvement (excluding DM1 and SMA) who were treated in the neonatal intensive care units of the France Southwest Reference Centres for Neuromuscular Diseases (Bordeaux-Montpellier-Toulouse) between 2007 and 2012 [1].
Diagnoses were made in five out of 19 cases, for a diagnostic yield of $26 \%$ (95\% CI [13;57]). The diagnoses were: distal spinal muscular atrophy type 1 with respiratory distress (SMARD1) ( $\mathrm{n}=1$ patient), congenital myotubular myopathy $(M T M)(n=1)$, congenital myasthenic syndromes (CHAT, RAPSN) $(\mathrm{n}=2)$, and nemalin myopathy NEM3 (ACTA1) $(\mathbf{n}=1)$.

The main objective of the current study was to evaluate the contribution of NGS to the diagnosis of congenital neuromuscular diseases with neonatal respiratory failure, using GPS targeted on the genes known to be responsible for congenital myopathies, congenital muscular dystrophies and several congenital myasthenic syndromes (MyoPanel; [2]).

\section{Patients and methods}

\subsection{Patients}

We carried out a retrospective multicentre diagnostic study on children hospitalised during the first month of life in the Neuropaediatric, Neonatology and Resuscitation Departments of the three paediatric facilities of the University Hospital Reference Centres in Bordeaux, Montpellier and Toulouse, between January 2007 and December 2018.

Inclusion criteria were the presence of peripheral hypotonia and/or arthrogryposis and the absence of neurological central signs in children who experienced respiratory distress during the first month of life. Exclusion criteria were the detection of SMA, DM1 and $P W S$ variants and no performance of congenital myopathy or muscular dystrophy panels.

\subsection{Clinical assessment}

Extensive patient details were collected during the first examination by a neuropaediatrician or a paediatric intensivist; this included the patient's age, reasons for hospitalisation and neurologic, muscular, respiratory, nutritional and orthopaedic features. Early disease onset was defined by the onset of symptoms of respiratory distress or muscular weakness before one month of age.

For children who died during the course of the study, we reported the date of death and specified whether a multidisciplinary palliative care meeting had been held prior to death.

\subsection{Paraclinical investigations}

A unique paraclinical examination protocol was implemented to investigate the aetiology of neonatal hypotonia according to previously reported recommendations [1] presented in Fig. 1. This comprised, as a bare minimum, creatine kinase (CK) assay, antiacetylcholine receptor antibody and anti-MuSK antibody studies coupled with a pyridostigmine assay, and electrophysiology studies that included electroencephalography (EEG) and electroneuromyography (ENMG), cerebral and medullary MRI, muscle biopsy, pangenomic CGH array, echocardiography, and chest and whole-skeleton X-rays.

Nerve, muscle and skin biopsies were fixed, paraffin-embedded, and sectioned with a microtome. Samples were analysed with an optical microscope and depicted by the local pathologist, sometimes after histoenzymological, immunohistochemical and ultrastructural study. Several patient biopsies required analysis by electron microscopy.

\subsection{Genetics}

The patients benefited from several myopathy and muscular dystrophy gene panels. One panel was composed of 18 genes 


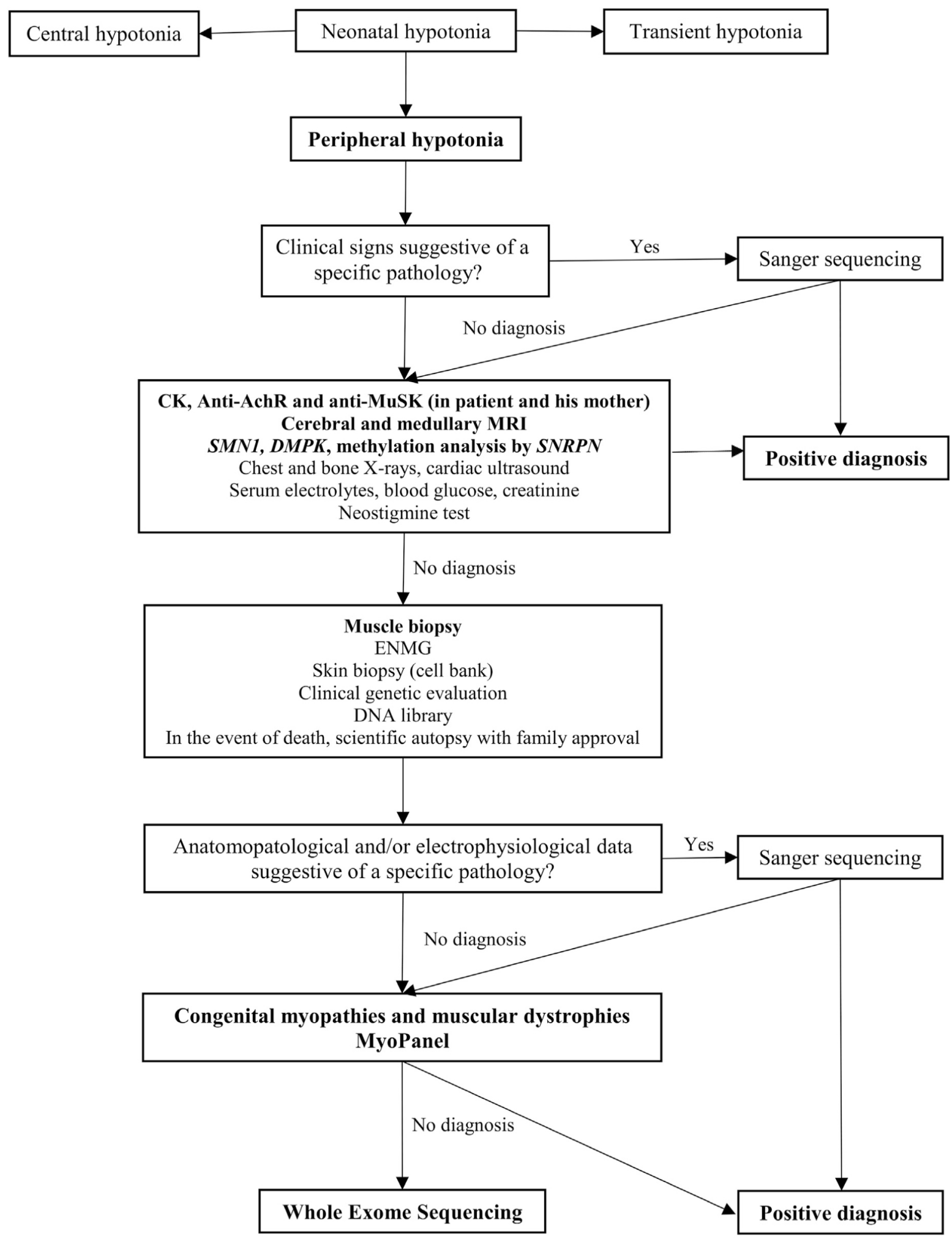

Fig. 1. Investigation protocol for patients with neonatal hypotonia suspected of being of neuromuscular origin.

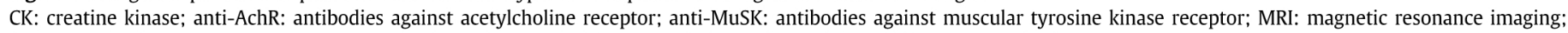
SMN1: survival motoneuron; DMPK: myotonic dystrophy protein kinase; DNA: deoxyribonucleic acid library; ENMG: electroneuromyogram.

(n = 1) (ACTA1, BIN1, CACNA1S, CCDC78, CFL2, DNM2, KLHL40, KLHL41, KBTBD13, MTM1, MYH7, NEB, RYR1, SEPN1, STAC3, TNNT1, TPM2, TPM3). Another panel, previously reported [2], was composed of 135 genes $(n=12)$ and was secondarily increased to 185 genes $(n=15)$ including 95 genes in which pathogenic variants have been reported in neonatal hypotonia (Neonatal hypotonia in silico panel, supplementary data panel NGS). Parents were also analysed by GPS when samples were available.

Coverage at a sequencing depth of $\geq 50$ X was more than $98.5 \%$. Bioinformatic analyses of the fastq files generated by Illumina 
sequencing, for single nucleotide variant (SNV) and copy number variant (CNV) detection, were performed using two independent pipelines, as previously described [2]. Variant pathogenicity was evaluated using criteria commonly used according to the American College of Medical Genetics and Genomics (ACMG) guidelines [45], as reported in Zenagui et al. in 2018 [2]. Variants were expected to be present in less than $1 \%$ of general population databases such as the Exome Aggregation Consortium (EXAC) and the Genome Aggregation Database (GnomAD). The prioritisation score using the MoBiDiC prioritisation algorithm (MPA; a 0-to-10 prioritisation score algorithm based on 10 pathogenicity prediction tools) was used to estimate the probability of pathogenicity [46].

Conventional Sanger sequencing was used to confirm candidate variants in patients and for familial segregation analyses [2].

\subsection{Evaluated parameters}

The primary endpoint was the MyoPanel genetic diagnostic yield for the total 2007-2018 cohort and for each of the two cohorts (i.e. 2007-2012 and 2013-2018). Secondary endpoints were the correlation between the clinical data and genotype, the muscle biopsy result and a positive genetic diagnosis, and the genephenotype profile of the identified genes. Diagnostic yield was the proportion of patients diagnosed by the tested technique among all cohort patients. Diagnostic gain was the proportion of additional patients diagnosed by the NGS technique compared to the Sanger technique in the same cohort.

\subsection{Statistical analysis}

Qualitative variables were expressed as percentages with 95\% confidence interval ( $95 \% \mathrm{CI}$ ). Data analysis was performed using Stata 14.2 software (Stata Corp., College Station, TX).

\subsection{Ethics approval}

The study was approved by the institutional ethics committee according to the guidelines issued by our institutions for clinical studies in compliance with the Helsinki Declaration (MR004: 2206723 v 0). Parents or legal guardians gave informed consent for the genetic analysis in accordance with the appropriate French legislation.

\section{Results}

\subsection{Population}

A total of 28 children from 26 different families were included in the current study, eight from the initial 2007-2012 cohort and 20 from the 2013-2018 cohort. The patients included in this study were extracted from the first cohort initially analysed between 2007 and $2012(n=19)$ completed with a new cohort of patients analysed between 2013 and $2018(n=22)$. From the initial 2007-2012 cohort of 19 eligible patients, six were diagnosed by Sanger sequencing, five patients died before NGS sampling, and the remaining eight patients (from 8 families) without molecular diagnosis were included in the present study. From the 2013-2018 cohort of 21 eligible patients, two patients were excluded: one patient had a muscle biopsy that oriented the diagnosis towards merosin deficiency and led to the confirmation of a LAMA2 pathogenic variant by Sanger sequencing, and the other patient, with neuropathic symptoms, was not screened against a MyoPanel but a neuropathic gene panel. Thus, 20 patients from 19 families were included in the study. One patient from the 2007-2012 cohort and one patient from the 2013-2018 cohort belong to the same family (Fig. 2).
Clinical features of the total cohort are summarised in Table 1. One third of the patients had a family history of neuromuscular disease. One half exhibited antenatal symptoms such as polyhydramnios and/or decreased foetal movements. Baseline clinical data indicated that $43 \%$ exhibited areflexia or arousal described as anomalous; joint retractions or arthrogryposis were present in $79 \%$ of the patients, associated with amimia in 76\%; and facial dysmorphism was identified in $36 \%$.

In terms of disease progression, 16 patients, i.e. $57 \%$ of the cohort, died half within the first month of life, 31\% between 1 and 3 months and 18\% between 3 months and 3 years. Of the 11 survivors (39\% of the cohort), 63\% learned to walk between 18 months and 3 years of age, although only two patients were younger than 1 year at the time of the first paediatric consultation. Two patients were lost to follow-up.

\subsection{Further examinations}

Molecular screens for pathogenic variants in SMN1 (SMA) and DMPK (DM1) and methylation analysis of SNRPN (PWS) were performed for all patients and yielded negative results (this was part of the inclusion criteria).

The muscle biopsy proved to be informative in 21 out of the 22 tested patients. In one patient, the analysis revealed a pattern of nonspecific congenital muscular dystrophy, whereas the remaining 20 patients displayed a pattern of congenital myopathy: nemaline myopathy ( $\mathrm{n}=5$ patients), centronuclear myopathy $(n=2)$, central core disease $(n=2)$, congenital fibre type disproportion $(n=4)$, myofibrillar myopathy with glycogen overload $(n=1)$, size irregularity of the fibres with lipid and mitochondrial overload ( $\mathrm{n}=1$ ), and nonspecific myopathic biopsy $(\mathrm{n}=5)$.

Among the 26 patients who performed a cerebral MRI, abnormalities were present in half of them $(n=13)$ : dystrophy or agenesis of the corpus callosum $(n=3)$, periventricular leukomalacia or periventricular white matter abnormalities $(n=5)$, a punctiform haemorrhage $(\mathbf{n}=1)$, minor ventriculomegaly or enlargement of the subarachnoid spaces $(n=3)$, and anoxoischaemic lesions $(n=1)$.

The electrophysiology studies revealed that six of the 14 examined patients exhibited EEG abnormalities. ENMG identified myogenic alterations in four patients and neurogenic alterations in one patient out of a total of 20 examined patients.

The remaining tests demonstrated poor cost-effectiveness: $32 \%$ of the 28 patients tested $(n=9)$ had an abnormal CK level of $>500$ $\mathrm{UI} / \mathrm{L}$. All results came back negative for the CGH array $(\mathrm{n}=11)$, karyotype $(\mathrm{n}=10)$ and anti-acetylcholine and anti-MuSK antibodies for myasthenia gravis diagnosis $(\mathbf{n}=19)$. Nonspecific wholebody radiological abnormalities were observed in $46 \%$ of 13 patients tested $(n=6)$ and thoracic abnormalities in $56 \%$ of 25 patients tested $(n=14)$. Cardiac ultrasound was anomalous in $27 \%$ of 22 patients tested $(n=6)$.

\subsection{Diagnostic yield of the MyoPanel}

fdb 9.1.450/W UnicodeOut of the 28 cohort patients, MyoPanel NGS identified causal molecular anomalies in 12 patients from 12 different families. This represented a total diagnostic yield of $43 \%$ (95\% CI $[24 ; 63])$ of the study population. The diagnostic yield was $63 \%(95 \% \mathrm{CI}[24 ; 91])(\mathrm{n}=5 / 8)$ for the $2007-2012$ cohort and $35 \%$ (95\% CI [15;59]) $(\mathrm{n}=7 / 20)$ for the $2013-2018$ cohort. The diagnostic yield of the MyoPanel was 50\% (95\% CI [28;72]) in patients who had previously had a muscle biopsy (11/22) and only $17 \%(95 \%$ CI $[0 ; 64])$ in patients without pathological analysis (1/6). Pathogenic variants were identified in the following genes: RYR1 $(\mathbf{n}=2)$, 


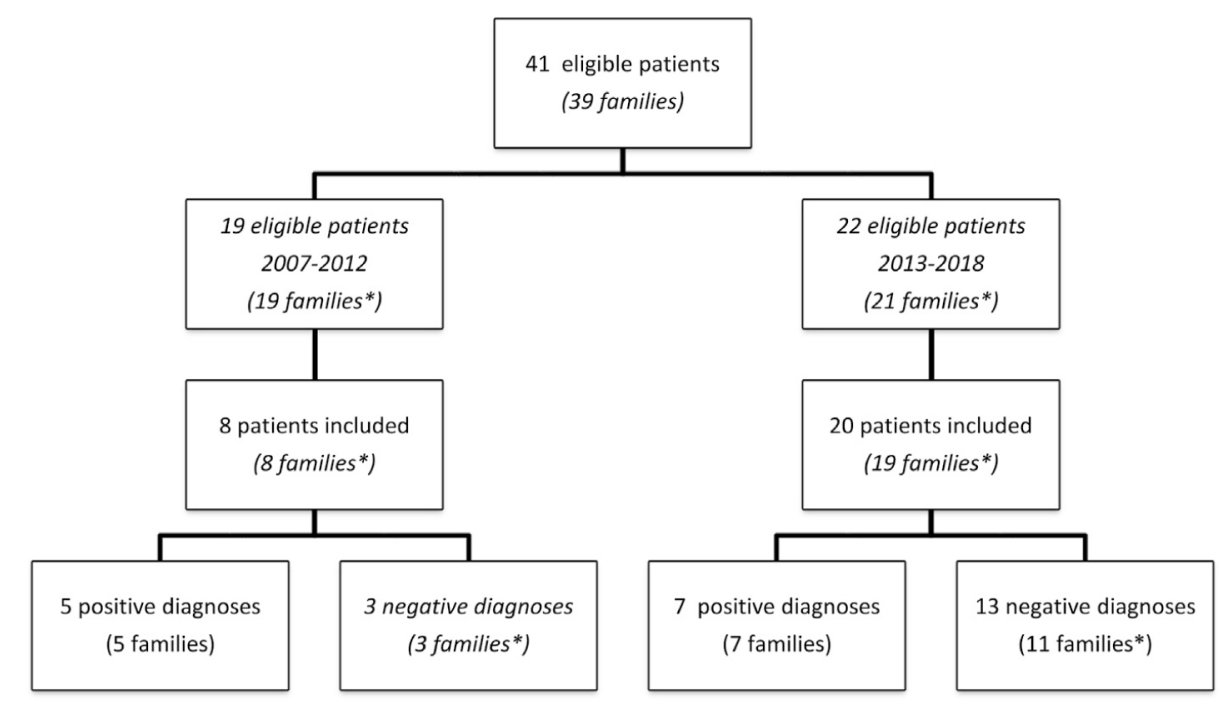

*1 patient from the 2007-2012 cohort and 1 patient from the 2013-2018 cohort belong to the same family

Fig. 2. Study diagram

Distribution of patients according to the two study cohorts and the results of the various genetic diagnostic techniques. *1 patient from the $2007-2012$ cohort and 1 patient from the 2013-2018 cohort belong to the same family.

ACTA1 $(\mathrm{n}=4), N E B(\mathrm{n}=3), \operatorname{MTM} 1(\mathrm{n}=2)$, and CACNA1S $(\mathrm{n}=1)$ (Table 2). The clinical, paraclinical and genetic characteristics of these patients (patients 1 to 12) are summarised in Table 3. Others patients characteristics (patients 13 to 28 ) are summarised in Supplementary Table 1.

\subsection{Genotype-phenotype correlation}

3.4.1. ACTA1 gene

ACTA1 gene pathogenic variants were detected in patients 1 to 4 $(\mathrm{n}=4 / 28)$. Three of these patients had an antenatal history of

Table 1

Clinical features of the cohort.

\begin{tabular}{|c|c|c|}
\hline & Number of patients & Percentage (\%) of patients \\
\hline \multicolumn{3}{|l|}{ Genders } \\
\hline Female & 14 & $50 \%$ \\
\hline Male & 14 & $50 \%$ \\
\hline Consanguinity & 2 & $7 \%$ \\
\hline Spontaneous miscarriage & 5 & $18 \%$ \\
\hline Family history of neuromuscular disease & 9 & $32 \%$ \\
\hline Antenatal signs & 14 & $50 \%$ \\
\hline Polyhydramnios and decreased perceived foetal movements & 6 & $21 \%$ \\
\hline Polyhydramnios only & 4 & $14 \%$ \\
\hline Decreased perceived foetal movements only & 4 & $14 \%$ \\
\hline Perinatal anoxia & 7 & $25 \%$ \\
\hline Prematurity & 5 & $18 \%$ \\
\hline Neonatal respiratory distress & 28 & $100 \%$ \\
\hline Intubation & 15 & $54 \%$ \\
\hline CPAP & 13 & $46 \%$ \\
\hline Ophthalmoplegia & 7 & $25 \%$ \\
\hline Orality disorders & $20 / 25$ & $80 \%$ \\
\hline Gastrostomy & $8 / 25$ & $32 \%$ \\
\hline Hypotonia & 28 & $100 \%$ \\
\hline Arthrogryposis & 22 & $79 \%$ \\
\hline Loss of tendon reflexes & 12 & $43 \%$ \\
\hline Amimia & $19 / 25$ & $76 \%$ \\
\hline Abnormal cognitive development & 12 & $43 \%$ \\
\hline Facial dysmorphism & 10 & $36 \%$ \\
\hline Death & $16^{\mathrm{a}}$ & $57 \%$ \\
\hline $0-1$ month & $8 / 16$ & $50 \%$ \\
\hline $1-3$ months & $5 / 16$ & $31 \%$ \\
\hline 3-months-3 years & $3 / 16$ & $18 \%$ \\
\hline Alive & 11 & $44 \%$ \\
\hline $\begin{array}{l}\text { Started walking } \\
\text { (18 months- } 3 \text { years) }\end{array}$ & $7 / 11$ & $63 \%$ \\
\hline
\end{tabular}

CPAP: continuous positive airway pressure.

${ }^{\text {a }}$ Two patients still alive were between 6 and 12 months at the time of investigation. Two patients were lost to follow-up. 
Table 2

Description of genetic pathogenic variants.

\begin{tabular}{|c|c|c|c|c|c|c|c|c|c|c|}
\hline Pati & Gene & Localisatio & Pathogenic variants & & $\begin{array}{l}\text { Mutation } \\
\text { effect }\end{array}$ & $\begin{array}{l}\text { Familial } \\
\text { segregation }\end{array}$ & $\begin{array}{l}\text { ExAC/ } \\
\text { gnomAD }\end{array}$ & $\begin{array}{l}\text { SIFT/ } \\
\text { Polyphen2 }\end{array}$ & $\begin{array}{l}\text { MPA } \\
\text { score }\end{array}$ & reference \\
\hline 1 & $\begin{array}{l}\text { ACTA1 } \\
\text { NM_001100.3 }\end{array}$ & Exon 3 & c. $449 \mathrm{C}>\mathrm{T}$ & p.(Thr150Ile) & Missense & Not tested & Absent & $\begin{array}{l}\text { S: - } \\
\text { Po: B } \\
(0.38)\end{array}$ & 9 & $\begin{array}{l}\text { Ref Zenagui et Jutas- } \\
\text { Morales et al., } \\
\text { submitted }\end{array}$ \\
\hline 2 & $\begin{array}{l}\text { ACTA1 } \\
\text { NM_001100.3 }\end{array}$ & Exon 7 & c. $1057 \mathrm{~A}>\mathrm{G}$ & p.(Thr353Ala) & Missense & de novo & Absent & $\begin{array}{l}\text { S: - } \\
\text { Po: D } \\
(0.91)\end{array}$ & 9 & $\begin{array}{l}\text { Ref Zenagui et Jutas- } \\
\text { Morales et al., } \\
\text { submitted }\end{array}$ \\
\hline 3 & $\begin{array}{l}\text { ACTA1 } \\
\text { NM_001100.3 }\end{array}$ & Exon 4 & c. $493 G>C$ & p.(Val165Leu) & Missense & de novo & Absent & $\begin{array}{l}\text { S: - } \\
\text { Po: D } \\
(0.93)\end{array}$ & 7.7 & $\begin{array}{l}\text { Ref Zenagui et Jutas- } \\
\text { Morales et al., } \\
\text { submitted }\end{array}$ \\
\hline 4 & $\begin{array}{l}\text { ACTA1 } \\
\text { NM_001100.3 }\end{array}$ & Exon 4 & c $553 C>T$ & p.(Arg185Cyr) & Missense & de novo & Absent & $\begin{array}{l}\text { S: - } \\
\text { Po: D } \\
(0.93)\end{array}$ & 7.7 & $\begin{array}{l}\text { Ref Zenagui et Jutas- } \\
\text { Morales et al., } \\
\text { submitted }\end{array}$ \\
\hline 5 & $\begin{array}{l}\text { RYR1 } \\
\text { NM_000540.2 }\end{array}$ & Exon 94 & c. $13740 \mathrm{~T}>\mathrm{G}$ & p.(Phe4580Leu) & Missense & de novo & Absent & $\begin{array}{l}\text { S: De } \\
(0.014) \\
\text { Po: D } \\
(0.99)\end{array}$ & 9 & This report \\
\hline 6 & $\begin{array}{l}\text { RYR1 } \\
\text { NM_000540.2 }\end{array}$ & $\begin{array}{l}\text { Exon } 76 \\
\text { Exon } 77\end{array}$ & $\begin{array}{l}\text { c. } 11122 A>C \\
\text { c. } 11186 T>C\end{array}$ & $\begin{array}{l}\text { p.(Thr3708Pro) } \\
\text { p.(Met3729Thr) }\end{array}$ & $\begin{array}{l}\text { Missense } \\
\text { Missense }\end{array}$ & Parents not tested & $\begin{array}{l}\text { Absent } \\
\text { Absent }\end{array}$ & $\begin{array}{l}\text { S: T } \\
(0.157) \\
\text { Po: P } \\
(0.876) \\
\text { S: De } \\
(0.021) \\
\text { Po: D } \\
(0.946)\end{array}$ & $\begin{array}{l}7 \\
9\end{array}$ & $\begin{array}{l}\text { Ref Zenagui et Jutas- } \\
\text { Morales et al., } \\
\text { submitted }\end{array}$ \\
\hline 7 & $\begin{array}{l}\text { MTM1 } \\
\text { NM_000252 }\end{array}$ & Exon 8 & c. $589 \mathrm{~A}>\mathrm{C}$ & p.(Thr197Pro) & Missense & Present in mother & Absent & $\begin{array}{l}\text { S: De } \\
(0,001) \\
\text { Po: D } \\
(0,997)\end{array}$ & 10 & This study \\
\hline 8 & $\begin{array}{l}\text { MTM1 } \\
\text { NM_000252.2 }\end{array}$ & Exon 5 & c. $290 \mathrm{G}>\mathrm{A}$ & p.(Gly97Glu) & Missense & $\begin{array}{l}\text { Present in mother } \\
\text { and maternal } \\
\text { uncles }\end{array}$ & Absent & $\begin{array}{l}\text { S: De } \\
(0.001) \\
\text { Po: D } \\
(0.999)\end{array}$ & 10 & $\begin{array}{l}\text { Ref Zenagui et Jutas- } \\
\text { Morales et al., } \\
\text { submitted }\end{array}$ \\
\hline 9 & $\begin{array}{l}\text { NEB } \\
\text { NM_001271208 } \\
\text { (compound } \\
\text { heterozygote)) }\end{array}$ & $\begin{array}{l}\text { Exon } 58 \\
\text { Intron } 62\end{array}$ & $\begin{array}{l}\text { c. } 8038 \mathrm{C}>\mathrm{T} \\
\text { c. } 8889+1 \mathrm{G}>\mathrm{A}\end{array}$ & p. $(\operatorname{Arg} 2680 *)$ & $\begin{array}{l}\text { Nonsense } \\
\text { Splice-site }\end{array}$ & $\begin{array}{l}\text { Inherited from } \\
\text { the father } \\
\text { Inherited from } \\
\text { the mother }\end{array}$ & $\begin{array}{l}\text { Absent } \\
\text { Absent }\end{array}$ & & $\begin{array}{l}10 \\
10\end{array}$ & $\begin{array}{l}\text { Ref Zenagui et Jutas- } \\
\text { Morales et al., } \\
\text { submitted }\end{array}$ \\
\hline 10 & $\begin{array}{l}\text { NEB } \\
\text { (NM_001271208.1 } \\
\text { (compound } \\
\text { heterozygote) }\end{array}$ & $\begin{array}{l}\text { Exon } 89 \\
\text { Intron } 47\end{array}$ & $\begin{array}{l}\text { c.13661_13666delinsA } \\
\text { c.6075+5G>A }\end{array}$ & p.(Ser4554Asnfs*10) & $\begin{array}{l}\text { Frameshift } \\
\text { Splice-site }\end{array}$ & $\begin{array}{l}\text { Inherited from } \\
\text { the mother } \\
\text { Inherited from } \\
\text { the father }\end{array}$ & $\begin{array}{l}\text { Absent } \\
\text { Absent }\end{array}$ & & $\begin{array}{l}10 \\
10\end{array}$ & $\begin{array}{l}\text { Ref Zenagui et Jutas- } \\
\text { Morales et al., } \\
\text { submitted }\end{array}$ \\
\hline 11 & $\begin{array}{l}\text { NEB } \\
\text { NM_001271208 } \\
\text { (NM_001271208.1 } \\
\text { (compound } \\
\text { heterozygote) }\end{array}$ & $\begin{array}{l}\text { Exon } 8 \\
\text { Exon } 168\end{array}$ & $\begin{array}{l}\text { c.518delA } \\
\text { c.23998dupG }\end{array}$ & $\begin{array}{l}\text { p.(Lys173Serfs*55) } \\
\text { p.(Glu8000Glyfs*11) }\end{array}$ & $\begin{array}{l}\text { Frameshift } \\
\text { Frameshift }\end{array}$ & $\begin{array}{l}\text { Inherited from } \\
\text { the mother } \\
\text { Inherited from } \\
\text { the father }\end{array}$ & $\begin{array}{l}\text { Absent } \\
\text { Absent }\end{array}$ & & $\begin{array}{l}10 \\
10\end{array}$ & $\begin{array}{l}\text { Ref Zenagui et Jutas- } \\
\text { Morales et al., } \\
\text { submitted }\end{array}$ \\
\hline 12 & $\begin{array}{l}\text { CACNA1S } \\
\text { NM_000069 } \\
\text { (compound } \\
\text { heterozygote) }\end{array}$ & $\begin{array}{l}\text { Exon } 20 \\
\text { Exon } 41\end{array}$ & $\begin{array}{l}\text { c. } 2618 \mathrm{del} \\
\text { c. } 5104 \mathrm{C}>\mathrm{T}\end{array}$ & $\begin{array}{l}\text { p.(Leu873Argfs*21) } \\
\text { p.(Arg1702*) }\end{array}$ & $\begin{array}{l}\text { Frameshift } \\
\text { Nonsense }\end{array}$ & $\begin{array}{l}\text { Inherited from } \\
\text { the father } \\
\text { Inherited from } \\
\text { the mother }\end{array}$ & $\begin{array}{l}0.009 \\
0.0000916\end{array}$ & & $\begin{array}{l}10 \\
10\end{array}$ & This report \\
\hline
\end{tabular}

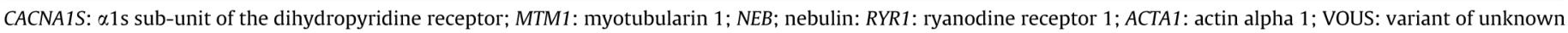

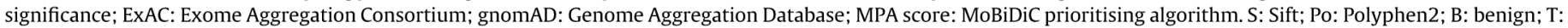
tolerated; De: deleterious; D: damaging; P: Probably damaging.

polyhydramnios or decreased foetal movement. One half of these patients suffered from arthrogryposis and areflexia. All presented with amimia and severe respiratory distress requiring invasive ventilatory support, but cognitive status was unaffected. Their anatomopathological profiles were extremely variable: an irregularity of the size of the fibres with lipid and mitochondrial overload (patient 1), myofibrillar disorganisation with glycogen deposition (patient 2), isolated perimysial and endomysial fibrosis (patient 3), and nemaline myopathy (patient 4). All pathogenic variants detected in our patients were de novo dominant missense variants.

\subsubsection{RYR1 gene}

The RYR1 gene was mutated in patients 5 and $6(n=2 / 28)$. Both patients had antenatal symptoms (polyhydramnios and decreased foetal movements), postpartum symptoms (respiratory distress requiring invasive ventilatory support, arthrogryposis, anomalous cognitive development, amimia, facial dysmorphism, ophthalmoplegia) and $\mathrm{CK}>1000 \mathrm{mmol} / \mathrm{l}$; both also died prematurely before one month. Patient 5 had a de novo RYR1 pathogenic variant, NM_000540.2: c.13740T>G; p.(Phe4580Leu), even though there was familial evidence of dominant transmission (family history of neuromuscular disease from the father and paternal uncles). The pathogenic nature of this variant is well established: the amino acid involved is highly conserved evolutionarily, is characterised by loss of an aromatic ring, and is not included in the polymorphism databases ExAC; bioinformatic analysis predicts a deleterious effect on protein function caused by damage to the TM1 transmembrane domain of the calcium channel. Its de novo aspect in the context of the family history of neuromuscular disease suggests the presence of an additional familial pathogenic variant. Patient 6 had two 
Table 3

Clinical phenotypes of genotyped patients.

\begin{tabular}{|c|c|c|c|c|c|c|c|c|c|c|c|c|}
\hline & ACTA1 & & & & RYR1 & & MTM1 & & NEB & & & CACNA1S \\
\hline Patients & 1 & 2 & 3 & 4 & 5 & 6 & 7 & 8 & 9 & 10 & 11 & 12 \\
\hline Cohort & A & A & A & $\mathrm{B}$ & A & $\mathrm{B}$ & $\mathrm{B}$ & B & B & A & B & $\mathrm{B}$ \\
\hline Gender & $\mathrm{F}$ & M & M & M & $\mathrm{F}$ & M & M & M & $\mathrm{M}$ & M & $\mathrm{F}$ & $\mathrm{M}$ \\
\hline Consanguinity & - & - & - & - & - & - & - & - & - & - & - & - \\
\hline Spontaneous miscarriage & - & - & - & - & - & + & + & - & + & - & - & - \\
\hline Family history & - & - & - & - & $\mathrm{AD}$ & - & - & $\mathrm{XL}$ & - & ID & - & - \\
\hline Polyhydramnios & + & - & - & - & + & + & + & - & + & - & - & - \\
\hline Fœtus with immobilism & - & + & - & + & + & + & + & - & + & - & + & - \\
\hline Prenatal anoxia & + & + & - & - & - & - & - & - & + & + & - & - \\
\hline Age at birth (weeks of pregnancy) & 40 & 38 & 41 & 39 & 31 & 38 & 41 & 39 & 38 & 34 & 38 & 38 \\
\hline Ventilatory support & TI & TI & TI & TI & TI & TI & CPAP & CPAP & $\mathrm{TI}$ & CPAP & TI & CPAP \\
\hline Ophthalmoplegia & - & - & - & - & + & + & + & - & & - & - & + \\
\hline Orality disorders & + & $\mathrm{Ga}$ & $\mathrm{Ga}$ & + & - & + & + & + & & + & & $\mathrm{Ga}$ \\
\hline Arthrogryposis & + & - & + & + & + & + & + & - & & + & + & - \\
\hline Loss of tendon reflexes & + & - & - & + & + & - & + & + & - & - & + & - \\
\hline Amimia & + & + & + & + & + & + & + & + & + & + & + & + \\
\hline Abnormal cognitive development & - & - & - & - & + & + & + & - & + & + & + & - \\
\hline Facial dysmorphism & - & - & - & - & + & + & - & - & + & + & + & - \\
\hline Started walking (months) & - & - & & - & - & - & - & 20 & - & - & & \\
\hline Death (d: days, m: months) & $62(d)$ & $35(\mathrm{~m})$ & - & $20(d)$ & $5(d)$ & $27(d)$ & $12(\mathrm{~m})$ & - & $5(d)$ & $3(d)$ & $50(d)$ & - \\
\hline MRI & $\mathrm{N}$ & $\mathrm{N}$ & $\mathrm{N}$ & $\mathrm{N}$ & $\mathrm{LM}$ & VM & $\mathrm{N}$ & & $\mathrm{N}$ & & $\mathrm{N}$ & $\mathrm{N}$ \\
\hline EMG & MS & $\mathrm{N}$ & & & & MS & $\mathrm{N}$ & $\mathrm{N}$ & MS & - & $\mathrm{N}$ & MS \\
\hline CK (UI/l) & 524 & & 470 & 300 & 1063 & 4291 & 75 & 185 & 258 & 271 & $\mathrm{~N}$ & 38 \\
\hline Muscular biopsy & I & MFM & Fibrosis & NM & NMB & CCD & & CNM & NM & NM & NM & CNM \\
\hline \multirow[t]{4}{*}{ Genes previously analysed by Sanger sequencing } & & CHRN & - & - & CHRN & - & - & SMARD1 & - & ACTA1 & - & - \\
\hline & & RAPSN & & & RAPSN & & & FMR1 & & TPM2 & & \\
\hline & & DOK7 & & & DOK7 & & & & & ТРМ3 & & \\
\hline & & CHAT & & & CHAT & & & & & TNNT1 & & \\
\hline NGS technology & DNAmP & & & & & & & & & & & \\
\hline
\end{tabular}

A: 2007-2012 cohort ; B : 2013-2018 cohort.

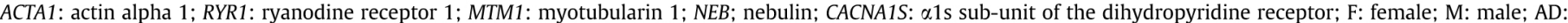

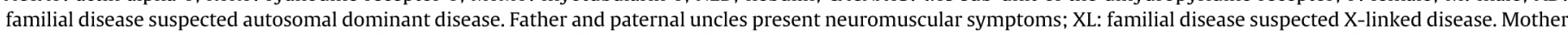

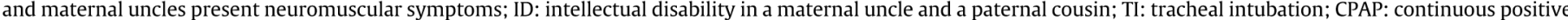

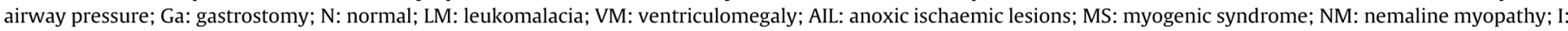

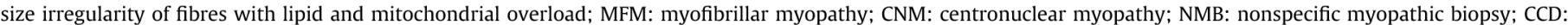
central core disease; CFTD: congenital fibre type disproportion ; DNAmP : mitochondrial DNA panel.

missense variants, one of them (c.11186T>C; p.(Met3729Thr)) being predicted as deleterious (absent in the general population ExAC, MPA score at 9, sift: 0.021, predicted deleterious, polyphen: 0.946 , predicted damaging), the other (c.11122A $>$ C; p.(Thr3708Pro)), predicted as probably pathogenic (absent in the general population, MPA score at 7, sift: 0.157 , predicted tolerated, polyphen:0.876 , probably damaging). Sift and polyphen give low pathogenicity prediction scores because the amino acid is in a poorly conserved domain in birds (but conserved up to the lamprey) and the physicochemical change is moderate. However, there is a loss of polarity and a rigidification of the domain caused by the substitution of a threonine by proline. The absence of available parents sample for segregation studies does not allow to conclude about a recessive effect of the variants or a dominant effect of the c.11186T>C; p.(Met3729Thr) variant alone.

\subsubsection{MTM1 gene}

Patients 7 and 8 carried an X-linked pathogenic variant in the MTM1 gene $(n=2 / 28)$. Both these patients were boys and experienced distal arthrogryposis, and one exhibited antenatal polyhydramnios with a decrease in foetal movements. Family segregation analysis of patient 8 relatives revealed a symptomatic involvement of the patient's maternal uncles, suggestive of an Xlinked recessive inheritance pattern. The presence of the MTM1 variant was confirmed in one maternal uncle. The patient, who is currently 4 years old, displayed normal or slightly delayed psychomotor development. On the other hand, patient 7 had a more unfavourable evolution and died at 12 months.

\subsubsection{Nebulin gene}

The three patients with NEB gene pathogenic variants (patients 9 to $11, \mathrm{n}=3 / 28$ ) presented with facial dysmorphism, amimia, abnormal cognitive development, and premature death (prior to 3 months of age), and two presented with antenatal symptoms. Patient 9 was diagnosed with hypospadias. From an anatomopathological perspective, these three patients systematically presented nemaline myopathy. Identified pathogenic variants included recessive splice-site, nonsense, or frameshift pathogenic variants. Each patient's pathogenic variant was inherited from one of the parents.

\subsubsection{CACNA1S gene}

Patient 12 was found to have a frameshift and a nonsense pathogenic variant in the CACNA1S gene. There was evidence of neonatal hypotonia with respiratory distress associated with ophthalmoplegia and amimia, with no other antenatal or postpartum symptoms. The muscle biopsy identified a centronuclear myopathy. Its progression at 12 months was encouraging and motor function showed gradual improvement.

\section{Discussion}

Neuromuscular diseases with neonatal respiratory involvement make up a group of heterogeneous pathologies with variable prognosis. They therefore present major challenges for the investigation of disease aetiology and therapeutic management. Despite an adapted protocol, their nonspecific semiological features make aetiological diagnosis difficult, except in cases with SMA and DM1 
pathogenic variants. We previously reported a diagnostic yield of $26 \%$ ( $n=5 / 19)$ by Sanger sequencing of single candidate genes based on phenotypic orientation in a cohort of 19 patients [1]. Compared to this time consuming approach, the one-step gene panel analysis reported in our study is faster and has a higher diagnostic yield, $43 \%(n=12 / 28)$. Originality of our study is the analysis of a cohort exclusively composed of newborns with hypotonia and neonatal respiratory distress, since such cohorts have not been reported in the literature. Among published data on the diagnostic effectiveness by GPS or WES of "early onset congenital neuromuscular disease", some studies include patients with neonatal onset. Wang et al. [47] conducted in 2016 a study on 186 hypotonic newborns with 22,5\% of efficiency of GPS with 35 neonatal hypotonia associated genes. Oliveira et al. [37] detected a diagnostic yield of $70 \%$ in a small sample of 12 patients, with five patients developing symptoms in the antenatal or neonatal period and two patients developing symptoms in childhood. Schofield et al. [30] evaluated the advantages of WES and GPS (464 neuromuscular genes panel) over conventional techniques in 56 patients suspected of having nemaline myopathy or congenital muscular dystrophy, with neonatal symptoms for $60 \%$ and early onset before one year for $20 \%$ of patients. All age, diagnostic yields were found to be $46 \%$ (26/56) for Sanger gene-by-gene approach, 75\% (42/56) for GPS and 79\% (44/56) for WES, that is comparable with GPS results. Vill et al. [36] conducted a study in 2017 on 98 patients under one year old and suspected of having myopathy; they used panels of between 99 and 152 genes and reported a diagnostic yield of 52\% (23/44 patients) ; WES revealed genetic diagnosis in 67\% (8/12 patients) . Todd et al. [41] investigated the effectiveness of NGS for diagnosing neuromuscular diseases in the antenatal and neonatal periods and found a diagnostic yield of $47 \%$ (18/38 families). Of the 18 diagnosed families, $12 / 23$ were identified with WES alone, $5 / 7$ by GPS alone (336 genes panel) and 1/8 using both techniques. Finally, in studies including patients with neonatal onset, WES is slightly more efficient than GPS with diagnostic yield between 52 and 79\% for WES and between 22.5 and 75\% for GPS ( [30,36,37,41,47]).

Our study identified pathogenic variants in the ACTA1, RYR1, MTM1, NEB and CACNA1S genes, the first four genes being known in neonatal hypotonia. Our patients phenotypes are similar to those in the literature [15,47-71]. Pathogenic variants in the CACNA1S gene, which were initially identified in dominant malignant hyperthermia [71], may also be implicated in dominant and recessive congenital myopathies. A study of 11 patients from seven families with CACNA1S congenital myopathies was conducted in 2016 [72]. Loss of function pathogenic variants was identified in the recessive forms and missense pathogenic variants in the dominant cases. Patients with recessive forms presented one frameshift variant with one frameshift, nonsense or missense variant. Our patient showed compound heterozygosity for two loss of function pathogenic variants. In terms of phenotype, neonatal hypotonia was reported in almost all patients and was associated with ophthalmoplegia in four out of 11 patients [72]. The pathological analysis was consistent with the patterns of centronuclear myopathies present in our patient.

The MyoPanel enabled a molecular diagnosis to be established for only five genes from a panel of 95 genes known to be involved in neonatal hypotonia, i.e. with only $5 \%$ of the panel used. This can be attributed in part to the very restrictive selection criteria of our population. Indeed, in a paediatric study described by Colombo et al. [15] in 2015, only 30\% of patients with myopathies met the criteria for "neonatal ventilatory support". This selection criterion for severe patients therefore excludes approximately two thirds of patients suspected of displaying neuromuscular disease symptoms during the neonatal period. Moreover, the lack of specific causes for neuromuscular pathologies manifesting during the neonatal period hinders the establishment of a short list of candidate genes for further analysis, thus justifying the use of a larger panel of genes that may be implicated in later manifestations of neuromuscular disease.

Half of our cohort was left with an equivocal molecular aetiology. There are several potential explanations for this poor result. The MyoPanel only investigates nuclear congenital myopathy, congenital muscular dystrophy and specific congenital myasthenic syndrome gene candidates, and therefore does not cover all aetiologies, notably all the genes associated with rare congenital myasthenic syndromes, mitochondrial myopathies, metabolic myopathies, specific anterior spinal cord syndromes and neuropathies. As the phenotype of hypotonia patients who are younger than one month old is quite subtle, the MyoPanel is sometimes erroneously performed, for lack of precise clinical orientation, in children who may actually present with a neurological impairment. In these cases, anatomopathological data should enable a more accurate selection of patients who would benefit from a MyoPanel analysis. This would explain the higher diagnostic yields in the 2007-2012 cohort (63\%) compared to the 2013-2018 cohort (35\%). Indeed, muscle biopsy was less systematic in the 2013-2018 cohort ( $n=15 / 20)$ than in the 2007-2012 cohort $(n=7 / 8)$, since anatomopathological analysis can identify features indicating a muscular and not central origin of the disorders. Muscle MRIs, which are very informative in older children, remain difficult to perform and interpret during the neonatal period.

We found no pathogenic variant in approximately two thirds of our patients, despite the presence of anatomopathological phenotypes supporting a myogenic process. This is quite a high rate, which raises the fundamental question of how many causative gene pathogenic variants still remain to be identified in these pathologies. This alone justifies the use of alternative methods such as WES, WGS and RNAseq. In our study, only five patients (from 4 families) benefited from a WES, but only one of these was decisive [73], a rather low degree of efficiency compared to data presented in the literature [36,41-43]. This alone justifies the use of alternative methods such as WES, WGS and RNAseq. In our study, five patients (from 4 families) benefited from a WES, and one of these was decisive [73]. The fact that WES is only slightly more efficient than GPS in the litterature $[30,36,37,74]$ could be related to the lack of investigation of intron regions, promoter regions, and regions that are prone to epigenetic modifications. WGS and RNA sequencing would therefore present significant advantages in the aetiological diagnosis of these pathologies. Results obtained from our cohort and evidence from the literature prompted us to modify the protocol for investigating neonatal hypotonia that is suspected of being of neuromuscular origin. We thus included a second-line WGS protocol to replace the GPS and WES approaches, as part of the "Plan France médecine génomique 2025". As part of the firstline assessment, we included an analysis of the MTM1 gene because a gene therapy protocol is available for patients with an early form of myotubular myopathy.

\section{Conclusion}

The congenital muscular myopathy and dystrophy panels are not enough efficiency in the diagnosis of peripheral neonatal hypotonia without suggestive clinical signs Indeed, over half of the neonatal peripheral hypotonia cases with early respiratory failure are refractory to diagnosis using this type of approach. We hope that systematic second-line screening by WGS of patients with neonatal hypotonia suspected of being of neuromuscular origin will lead to a major improvement in diagnostic performance in these pathologies. 
Declaration of competing interest

The authors have no conflict of interest to declare.

\section{Acknowledgments}

We thank the patients and families for their participation in the study. The findings herein are solely the responsibility of the authors. This work was supported by the Association AT3C (JO W311002244), a local non-profit association promoting the development of paediatric neurology and neuropsychology.

\section{References}

[1] J. Raignoux, U. Walther-Louvier, C. Espil, L. Berthomieu, E. Uro-Coste, F. Rivier, et al., [Congenital neuromuscular diseases with neonatal respiratory failure excluding myotonic dystrophy type 1 and infantile spinal muscular atrophy. Diagnosis strategy according to a 19-child series], Arch. Pediatr. Organe Off. Soc. Francaise Pediatr. 23 (9) (sept 2016) 878-886.

[2] R. Zenagui, D. Lacourt, H. Pegeot, K. Yauy, R. Juntas Morales, C. Theze, et al., A reliable targeted next-generation sequencing strategy for diagnosis of myopathies and muscular dystrophies, especially for the giant titin and nebulin genes, J. Mol. Diagn. JMD 20 (4) (2018) 533-549.

[3] E.C. Oates, K.J. Jones, S. Donkervoort, A. Charlton, S. Brammah, J.E. Smith, et al., Congenital Titinopathy: comprehensive characterization and pathogenic insights, Ann. Neurol. 83 (6) (2018) 1105-1124.

[4] P.B. Kang, L. Morrison, S.T. Iannaccone, R.J. Graham, C.G. Bönnemann, A. Rutkowski, et al., Evidence-based guideline summary: evaluation, diagnosis, and management of congenital muscular dystrophy: report of the guideline development subcommittee of the American academy of neurology and the practice issues review panel of the American association of neuromuscular \& electrodiagnostic medicine, Neurology 84 (13) (31 mars 2015) 1369-1378.

[5] C.G. Bönnemann, C.H. Wang, S. Quijano-Roy, N. Deconinck, E. Bertini, A. Ferreiro, et al., Diagnostic approach to the congenital muscular dystrophies, Neuromuscul. Disord. NMD 24 (4) (avr 2014) 289-311.

[6] K.G. Claeys, Congenital myopathies: an update, Dev. Med. Child Neurol. 62 (3) (2020) 297-302.

[7] V. Laugel, M. Cossée, J. Matis, A. de Saint-Martin, A. Echaniz-Laguna, J.L. Mandel, et al., Diagnostic approach to neonatal hypotonia: retrospective study on 144 neonates, Eur. J. Pediatr. 167 (5) (mai 2008) 517-523.

[8] D.C. Schorling, J. Kirschner, C.G. Bönnemann, Congenital muscular dystrophies and myopathies: an overview and update, Neuropediatrics 48 (4) (2017) $247-261$.

[9] X.-N. Fu, H. Xiong, Genetic and clinical advances of congenital muscular dystrophy, Chin. Med. J. (Engl) 130 (21) (5 nov 2017) 2624-2631.

[10] A.G. Engel, Genetic basis and phenotypic features of congenital myasthenic syndromes, Handb. Clin. Neurol. 148 (2018) 565-589.

[11] C. Farmakidis, M. Pasnoor, R.J. Barohn, M.M. Dimachkie, Congenital myasthenic syndromes: a clinical and treatment approach, Curr. Treat. Options Neurol. 20 (9) (21 juill 2018) 36.

[12] P.B. Shieh, S.J. Oh, Congenital myasthenic syndromes, Neurol. Clin. 36 (2) (2018) 367-378.

[13] B. Fauroux, A. Amaddeo, S. Quijano-Roy, C. Barnerias, I. Desguerre, S. Khirani, Respiratory insight to congenital muscular dystrophies and congenital myopathies and its relation to clinical trial, Neuromuscul. Disord. NMD 28 (9) (2018) 731-740.

[14] K.N. North, C.H. Wang, N. Clarke, H. Jungbluth, M. Vainzof, J.J. Dowling, et al., Approach to the diagnosis of congenital myopathies, Neuromuscul. Disord. NMD 24 (2) (févr 2014) 97-116.

[15] I. Colombo, M. Scoto, A.Y. Manzur, S.A. Robb, L. Maggi, V. Gowda, et al., Congenital myopathies: natural history of a large pediatric cohort, Neurology 84 (1) (6 janv 2015) 28-35.

[16] D. Cassandrini, R. Trovato, A. Rubegni, S. Lenzi, C. Fiorillo, J. Baldacci, et al., Congenital myopathies: clinical phenotypes and new diagnostic tools, Ital. J. Pediatr. 43 (1) (15 nov 2017) 101.

[17] H. Jungbluth, J. Ochala, S. Treves, M. Gautel, Current and future therapeutic approaches to the congenital myopathies, Semin. Cell Dev. Biol. 64 (2017) $191-200$.

[18] H. Jungbluth, S. Treves, F. Zorzato, A. Sarkozy, J. Ochala, C. Sewry, et al., Congenital myopathies: disorders of excitation-contraction coupling and muscle contraction, Nat. Rev. Neurol. 14 (3) (2018) 151-167.

[19] R. Falsaperla, A.D. Praticò, M. Ruggieri, E. Parano, R. Rizzo, G. Corsello, et al., Congenital muscular dystrophy: from muscle to brain, Ital. J. Pediatr. 42 (1)
(31 août 2016) 78.

[20] H.D. Gonorazky, C.G. Bönnemann, J.J. Dowling, The genetics of congenital myopathies, Handb. Clin. Neurol. 148 (2018) 549-564.

[21] A.E. Volk, C. Kubisch, The rapid evolution of molecular genetic diagnostics in neuromuscular diseases, Curr. Opin. Neurol. 30 (5) (2017) 523-528.

[22] M. Schuelke, N.C. Øien, A. Oldfors, Myopathology in the times of modern genetics, Neuropathol. Appl. Neurobiol. 43 (1) (févr 2017) 44-61.

[23] M. Savarese, G. Di Fruscio, M. Mutarelli, A. Torella, F. Magri, F.M. Santorelli, et al., MotorPlex provides accurate variant detection across large muscle genes both in single myopathic patients and in pools of DNA samples, Acta Neuropathol. Commun. 2 (11 sept 2014) 100.

[24] N. Vasli, J. Böhm, S. Le Gras, J. Muller, C. Pizot, B. Jost, et al., Next generation sequencing for molecular diagnosis of neuromuscular diseases, Acta Neuropathol. 124 (2) (août 2012) 273-283.

[25] M. Kuhn, D. Gläser, P.R. Joshi, S. Zierz, S. Wenninger, B. Schoser, et al., Utility of a next-generation sequencing-based gene panel investigation in German patients with genetically unclassified limb-girdle muscular dystrophy, J. Neurol. 263 (4) (avr 2016) 743-750.

[26] A. Ankala, C. da Silva, F. Gualandi, A. Ferlini, L.J.H. Bean, C. Collins, et al., A comprehensive genomic approach for neuromuscular diseases gives a high diagnostic yield, Ann. Neurol. 77 (2) (févr 2015) 206-214.

[27] A. Evilä, M. Arumilli, B. Udd, P. Hackman, Targeted next-generation sequencing assay for detection of mutations in primary myopathies, Neuromuscul. Disord. NMD 26 (1) (janv 2016) 7-15.

[28] J.H. Chae, V. Vasta, A. Cho, B.C. Lim, Q. Zhang, S.H. Eun, et al., Utility of next generation sequencing in genetic diagnosis of early onset neuromuscular disorders, J. Med. Genet. 52 (3) (mars 2015) 208-216.

[29] A. Sevy, M. Cerino, S. Gorokhova, E. Dionnet, Y. Mathieu, A. Verschueren, et al., Improving molecular diagnosis of distal myopathies by targeted nextgeneration sequencing, J. Neurol. Neurosurg. Psychiatry 87 (3) (mars 2016) 340-342.

[30] D. Schofield, K. Alam, L. Douglas, R. Shrestha, D.G. MacArthur, M. Davis, et al., Cost-effectiveness of massively parallel sequencing for diagnosis of paediatric muscle diseases, NPJ Genomic Med. 2 (2017).

[31] G.L. O'Grady, M. Lek, S.R. Lamande, L. Waddell, E.C. Oates, J. Punetha, et al., Diagnosis and etiology of congenital muscular dystrophy: we are halfway there, Ann. Neurol. 80 (1) (2016) 101-111.

[32] X. Tian, W.-C. Liang, Y. Feng, J. Wang, V.W. Zhang, C.-H. Chou, et al., Expanding genotype/phenotype of neuromuscular diseases by comprehensive target capture/NGS, Neurol. Genet. 1 (2) (août 2015) e14.

[33] B.B. Cummings, J.L. Marshall, T. Tukiainen, M. Lek, S. Donkervoort, A.R. Foley, et al., Improving genetic diagnosis in Mendelian disease with transcriptome sequencing, Sci. Transl. Med. 19 (386) (2017), 9.

[34] Savarese, et al., The genetic basis of undiagnosed muscular dystrophies and myopathies: results from 504 patients, Neurology 90 (23) (5 juin 2018) 1084.

[35] J. Punetha, A. Kesari, P. Uapinyoying, M. Giri, N.F. Clarke, L.B. Waddell, et al., Targeted Re-sequencing emulsion PCR panel for myopathies: results in 94 cases, J. Neuromuscul. Dis. 27 (2) (2016) 209-225, 3.

[36] K. Vill, A. Blaschek, D. Gläser, M. Kuhn, T. Haack, B. Alhaddad, et al., Early-onset myopathies: clinical findings, prevalence of subgroups and diagnostic approach in a single neuromuscular referral center in Germany, J. Neuromuscul. Dis. 4 (4) (2017) 315-325.

[37] J. Oliveira, A. Gonçalves, R. Taipa, M. Melo-Pires, M.E. Oliveira, J.L. Costa, et al., New massive parallel sequencing approach improves the genetic characterization of congenital myopathies, J. Hum. Genet. 61 (6) (juin 2016) 497-505.

[38] V. Nigro, M. Savarese, Next-generation sequencing approaches for the diagnosis of skeletal muscle disorders, Curr. Opin. Neurol. 29 (5) (2016) 621-627.

[39] M.M. Weiss, B. Van der Zwaag, J.D.H. Jongbloed, M.J. Vogel, H.T. Brüggenwirth, R.H. Lekanne Deprez, et al., Best practice guidelines for the use of nextgeneration sequencing applications in genome diagnostics: a national collaborative study of Dutch genome diagnostic laboratories, Hum. Mutat. 34 (10) (oct 2013) 1313-1321.

[40] W. Kress, S. Rost, K. Kolokotronis, G. Meng, N. Pluta, C. Müller-Reible, The genetic approach: next-generation sequencing-based diagnosis of congenital and infantile myopathies/muscle dystrophies, Neuropediatrics 48 (4) (2017) 242-246.

[41] E.J. Todd, K.S. Yau, R. Ong, J. Slee, G. McGillivray, C.P. Barnett, et al., Next generation sequencing in a large cohort of patients presenting with neuromuscular disease before or at birth, Orphanet J. Rare Dis. 10 (17 nov 2015) 148.

[42] R. Ghaoui, S.T. Cooper, M. Lek, K. Jones, A. Corbett, S.W. Reddel, et al., Use of whole-exome sequencing for diagnosis of limb-girdle muscular dystrophy: outcomes and lessons learned, JAMA Neurol. 72 (12) (déc 2015) 1424-1432.

[43] Z. Fattahi, Z. Kalhor, M. Fadaee, R. Vazehan, E. Parsimehr, A. Abolhassani, et al., Improved diagnostic yield of neuromuscular disorders applying clinical exome sequencing in patients arising from a consanguineous population, Clin. Genet. 91 (3) (2017) 386-402.

[44] V. Biancalana, J. Laporte, Diagnostic use of massively parallel sequencing in neuromuscular diseases: towards an integrated diagnosis, J. Neuromuscul. Dis. 2 (3) (2 sept 2015) 193-203.

[45] S. Richards, N. Aziz, S. Bale, D. Bick, S. Das, J. Gastier-Foster, et al., Standards and guidelines for the interpretation of sequence variants: a joint consensus recommendation of the American College of medical genetics and genomics and the association for molecular pathology, Genet. Med. Off. J. Am. Coll. Med. Genet. 17 (5) (mai 2015) 405-424. 
[46] K. Yauy, D. Baux, H. Pegeot, C. Van Goethem, C. Mathieu, T. Guignard, et al., MoBiDiC prioritization algorithm, a free, accessible, and efficient pipeline for single-nucleotide variant annotation and prioritization for next-generation sequencing routine molecular diagnosis, J. Mol. Diagn. JMD 20 (4) (2018) 465-473.

[47] Y. Wang, W. Peng, H.-Y. Guo, H. Li, J. Tian, Y.-J. Shi, et al., Next-generation sequencing-based molecular diagnosis of neonatal hypotonia in Chinese Population, Sci. Rep. [Internet] (29 juin 2016) [cité 29 nov 2020];6. Disponible sur, https://www.ncbi.nlm.nih.gov/pmc/articles/PMC4926250/.

[48] N. Witting, P. Laforêt, N.C. Voermans, N. Roux-Buisson, F. Bompaire, J. Rendu, et al., Phenotype and genotype of muscle ryanodine receptor rhabdomyolysismyalgia syndrome, Acta Neurol. Scand. 137 (5) (mai 2018) 452-461.

[49] L. Maggi, M. Scoto, S. Cirak, S.A. Robb, A. Klein, S. Lillis, et al., Congenital myopathies-clinical features and frequency of individual subtypes diagnosed over a 5-year period in the United Kingdom, Neuromuscul. Disord. NMD 23 (3) (mars 2013) 195-205.

[50] P.B. Agrawal, C.D. Strickland, C. Midgett, A. Morales, D.E. Newburger, M.A. Poulos, et al., Heterogeneity of nemaline myopathy cases with skeletal muscle alpha-actin gene mutations, Ann. Neurol. 56 (1) (juill 2004) 86-96.

[51] B. Ilkovski, S.T. Cooper, K. Nowak, M.M. Ryan, N. Yang, C. Schnell, et al., Nemaline myopathy caused by mutations in the muscle alpha-skeletal-actin gene, Am. J. Hum. Genet. 68 (6) (juin 2001) 1333-1343.

[52] M.M. Ryan, C. Schnell, C.D. Strickland, L.K. Shield, G. Morgan, S.T. Iannaccone, et al., Nemaline myopathy: a clinical study of 143 cases, Ann. Neurol. 50 (3) (sept 2001) 312-320.

[53] W. Wallefeld, S. Krause, K.J. Nowak, D. Dye, R. Horváth, Z. Molnár, et al., Severe nemaline myopathy caused by mutations of the stop codon of the skeletal muscle alpha actin gene (ACTA1), Neuromuscul. Disord. NMD 16 (9-10) (oct 2006) 541-547.

[54] C. de AM. Moreno, O. Abath Neto, S. Donkervoort, Y. Hu, U.C. Reed A.S.B. Oliveira, et al., Clinical and histologic findings in ACTA1-related nemaline myopathy: case series and review of the literature, Pediatr. Neurol. 75 (oct 2017) 11-16.

[55] S. Donkervoort, S.H.S. Chan, L.H. Hayes, N. Bradley, D. Nguyen, M.E. Leach, et al., Cytoplasmic body pathology in severe ACTA1-related myopathy in the absence of typical nemaline rods, Neuromuscul. Disord. NMD 27 (6) (juin 2017) 531-536.

[56] N.G. Laing, D.E. Dye, C. Wallgren-Pettersson, G. Richard, N. Monnier, S. Lillis, et al., Mutations and polymorphisms of the skeletal muscle alpha-actin gene (ACTA1), Hum. Mutat. 30 (9) (sept 2009) 1267-1277.

[57] J.-J. Feng, S. Marston, Genotype-phenotype correlations in ACTA1 mutations that cause congenital myopathies, Neuromuscul. Disord. NMD 19 (1) (janv 2009) 6-16.

[58] A. Hernandez-Lain, I. Husson, N. Monnier, C. Farnoux, G. Brochier, E. Lacène, et al., De novo RYR1 heterozygous mutation (I4898T) causing lethal core-rod myopathy in twins, Eur. J. Med. Genet. 54 (1) (févr 2011) 29-33.

[59] R. Attali, S. Aharoni, S. Treves, O. Rokach, M. Becker Cohen, Y. Fellig, et al., Variable myopathic presentation in a single family with novel skeletal RYR1 mutation, PloS One 8 (7) (2013), e69296.

[60] M. Snoeck, B.G.M. van Engelen, B. Küsters, M. Lammens, R. Meijer, J.P.F. Molenaar, et al., RYR1-related myopathies: a wide spectrum of phenotypes throughout life, Eur. J. Neurol. 22 (7) (juill 2015) 1094-1112.

[61] K. Amburgey, E. Tsuchiya, S. de Chastonay, M. Glueck, R. Alverez, C.-T. Nguyen, et al., A natural history study of X-linked myotubular myopathy, Neurology 89 (13) (26 sept 2017) 1355-1364.

[62] K. Amburgey, A. Bailey, J.H. Hwang, M.A. Tarnopolsky, C.G. Bonnemann, L. Medne, et al., Genotype-phenotype correlations in recessive RYR1-related myopathies, Orphanet J. Rare Dis. 8 (6 août 2013) 117.

[63] D.X. Bharucha-Goebel, M. Santi, L. Medne, K. Zukosky, K. Zukosky, J. Dastgir, et al., Severe congenital RYR1-associated myopathy: the expanding clinicopathologic and genetic spectrum, Neurology 80 (17) (23 avr 2013) $1584-1589$.

[64] M. Annoussamy, C. Lilien, T. Gidaro, E. Gargaun, V. Chê, U. Schara, et al., Xlinked myotubular myopathy: a prospective international natural history study, Neurology 16 (16) (2019), 92, e1852-67.

[65] J.J. Dowling, M.W. Lawlor, S. Das, X-linked myotubular myopathy, in: M.P. Adam, H.H. Ardinger, R.A. Pagon, S.E. Wallace, L.J. Bean, K. Stephens, et al.

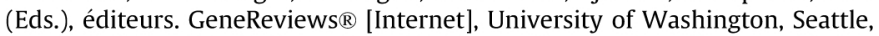
Seattle (WA), 1993 [cité 4 juill 2020]. Disponible sur: http://www.ncbi.nlm. nih.gov/books/NBK1432/.

[66] C. Wallgren-Pettersson, K. Donner, C. Sewry, E. Bijlsma, M. Lammens, K. Bushby, et al., Mutations in the nebulin gene can cause severe congenital nemaline myopathy, Neuromuscul. Disord. NMD 12 (7-8) (oct 2002) 674-679.

[67] J.-M. Lee, J.G. Lim, J.-H. Shin, Y.-E. Park, D.-S. Kim, Clinical and genetic diversity of nemaline myopathy from a single neuromuscular center in Korea, J. Neurol. Sci. 383 (15 déc 2017) 61-68.

[68] M. Feingold-Zadok, D. Chitayat, K. Chong, M. Injeyan, P. Shannon, D. Chapmann, et al., Mutations in the NEB gene cause fetal akinesia/ arthrogryposis multiplex congenita, Prenat. Diagn. 37 (2) (févr 2017) 144-150.

[69] D. Piga, F. Magri, D. Ronchi, S. Corti, D. Cassandrini, E. Mercuri, et al., New mutations in NEB gene discovered by targeted next-generation sequencing in nemaline myopathy Italian patients, J. Mol. Neurosci. MN 59 (3) (juill 2016) $351-359$.

[70] V.-L. Lehtokari, K. Kiiski, S.A. Sandaradura, J. Laporte, P. Repo, J.A. Frey, et al., Mutation update: the spectra of nebulin variants and associated myopathies, Hum. Mutat. 35 (12) (déc 2014) 1418-1426.

[71] D.M. Miller, C. Daly, E.M. Aboelsaod, L. Gardner, S.J. Hobson, K. Riasat, et al., Genetic epidemiology of malignant hyperthermia in the UK, Br. J. Anaesth. 121 (4) (oct 2018) 944-952.

[72] V. Schartner, N.B. Romero, S. Donkervoort, S. Treves, P. Munot, T.M. Pierson, et al., Dihydropyridine receptor (DHPR, CACNA1S) congenital myopathy, Acta Neuropathol. 133 (4) (2017) 517-533.

[73] M. Pergande, S. Motameny, Ö. Özdemir, M. Kreutzer, H. Wang, H.S. Daimagüler, et al., The genomic and clinical landscape of fetal akinesia, Genet. Med. Off. J. Am. Coll. Med. Genet. 22 (3) (2020) 511-523.

[74] E.J. Todd, K.S. Yau, R. Ong, J. Slee, G. McGillivray, C.P. Barnett, et al., Next generation sequencing in a large cohort of patients presenting with neuromuscular disease before or at birth, Orphanet J. Rare Dis. 10 (17 nov 2015) 148. 